\title{
Laws, doctrines and practice A study of intermarriages and the ways they challenged the Jewish Community of Helsinki from 1930 to 1970
}

\author{
Mercédesz Czimbalmos
}

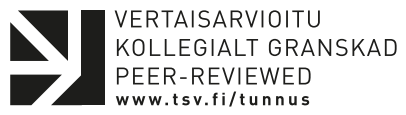

DOI: https://doi.org/10.30752/nj.77260

Aвstract - The identities, customs and habits of religious congregations are tightly connected to the history of these congregations and to the specific religious tradition or denomination they consider themselves to be a part of. They are also shaped by the legislative and bureaucratic regulations and processes of the secular society that is surrounding them. The aim of this study is to further our knowledge of some of these aspects of Jewish life as they relate to the Jewish Community of Helsinki in the period $1930-70$ by showcasing two examples that emerged as a result of the rising number of intermarriages in the congregation.

\section{Introduction}

Religious congregations around the world have their distinctive identities, customs and habits, which are tightly linked to the history of the congregation and of the country. They are shaped by the specific religious traditions that the community considers itself to be a part of but are also significantly influenced by the (secular) world surrounding the congregation. Understanding how a religious community works requires knowledge of all these aspects of life (Ammerman I 998: 78-80).

The aim of this study is to enhance the understanding of the Jewish Community of Helsinki and to showcase two empirical examples (registration of halakhically nonJewish children of mixed marriages in the community's membership books and the case of a rabbinical regulation) in the period I930-70 that emerged in the congregation as a result of the rising number of intermarriages.

\section{Theoretical framework}

Until the early modern period, the majority of Jews lived segregated, isolated lives. Marital liaisons between them and people of other faiths were limited, and legally impossible (Bleich 201 5:3). The previously evident boundaries and markers between the Jewish minority and non-Jewish society began to dissolve as the rights of Jewish people were expanded as a result of socio-economic and religious changes (Buckser 2003; Berman 20Io; Bleich 2015). Hence, by the mid-nineteenth century, intermarriages between Jews and people of other faiths had become a prevalent phenomenon in most European countries. Today, rates of Jewish intermarriage have risen remarkably high in most countries (Bleich 2015:3).

As highlighted by international research, the growing number of exogamous marriages is one of the key issues for Jewish communities globally (Buckser 2003; Graham 2004, 2016; Dencik 2003; Hirt et al. 2015; Fishman 
and Cohen 2017). Demographic concerns on the topic include the threat of discontinuation of distinct Jewish ethnicity and the identities of children of intermarried couples (Tobin and Simon I999; Graham 2004; Fishman 20I 5; Sasson et al. 201 5 ; Fishman and Cohen 20I7). Religious concerns that emerge in the context of intermarriages include debates on patrilineal descent, conversion, acceptance of children born to non-Jewish mothers and the status of Jews who marry out of the faith (Cohen I998; Buckser 2003; Tank-Storper 2013; Sarna 201 5 ).

In the Finnish context, no specific studies have been conducted into Finnish-Jewish intermarriages. The theologian Elina Vuola in her project entitled 'Embodied Religion: Changing Meanings of Body and Gender in Contemporary Forms of Religion in Finland' (Vuola 20I8) has conducted a wider range of research on religiosity among women in Finland in several denominations, touching upon the transitions that appeared in the Jewish communities (Vuola, in the current issue). Recent studies tightly relating to the issue of interreligious marriages in Finland were only created from the perspectives of Christian Orthodox-Lutheran intermarriages (Honkasalo 2015; Kupari 2016). Prior to these studies, the theologian Voitto Huotari implemented a quantitative research on Christian Orthodox-Lutheran intermarriages (Huotari 1975). The discussion indicates that intermarriages bring about changes in religious behaviour and may influence the religious system and practices (Honkasalo 2016; Kupari 2016; Huotari r 975). Some of these changes that occur as a result of intermarriages may increase discrepancies between the organisation of the religious community, the doctrines and their interpretations and the empirical, vernacular behaviour. Congregations often rely on a responsible authority when choosing how to resolve the issues that arise from the situation (Huotari I 975: 292-3). As the material in the current study indicates, the Jewish Community of Helsinki was significantly influenced by the rising number of intermarriages. The congregation, its members and leadership faced challenges related to legislation, administration and religious interpretation of these intermarriages.

In order to fill the void in the scientific research into intermarriages - and FinnishJewish intermarriages in particular - this study aims to answer the following research questions: How were changes in Finnish society reflected in the Jewish Community of Helsinki in the period I930-70? How did the community respond to the changes that were brought upon them? What impact did the increasing number of intermarriages have on the community in the period studied, and what approach or approaches did the leadership of the congregation choose to resolve the tensions generated from their practices?

To answer these questions, I first introduce the Finnish legislative background at the beginning of the twentieth century. ${ }^{1}$ Then, I briefly present some of the rabbis of the Jewish Community of Helsinki, since they contributed significantly to the religious perceptions of the congregation. In the last part of the article, I move on to the key phenomenon identified in the research process: the growing number of intermarriages and the discourse centred around them during the period studied, as illustrated by two examples.

1 As this article is a part of a special issue, I decided not to give a general introduction to the history of Finnish Jewry in this article as it is included in the editorial of the issue itself. 


\section{Research material and terminology}

This study focuses on some of the questions that arose partially as a result of the rising numbers of intermarriages in the community, mainly in the period I930-70. This particular period was chosen after careful evaluation of the currently available data. The data indicated that the number of intermarriages in the Jewish Community of Helsinki started rising around the year I930. Moreover - as mentioned later - the Freedom of Religion Act was changed in I969 (LUM767/r 969), which marks a transition in practices and thus forms a natural end point for the current analysis. The research material was assembled by focusing on the issues of congregational practices that were affected by the intermarriages occurring in the community.

Throughout the article, as a basis of my terminology, I use the paper of Sergio DellaPergola entitled 'Jewish out-marriage: a global perspective' (DellaPergola 2003). I categorise the marital unions as follows:

Intermarriage. A larger category, which refers to officially registered marital unions, in which the spouses belong(ed) to different religious communities, ${ }^{2}$ or in which only one of the spouses belonged to a religious community of any sort. ${ }^{3}$

Civil marriage. A category that applies to marriages that were officiated by a state officer in Finland or abroad. I consider all marriages that were officiated in Israel Jewish religious marriages.

2 For example, one spouse is registered as Lutheran and the other spouse is registered as Jewish.

3 For example, one spouse is registered as Jewish and the other spouse is registered in the civil register.
Mixed marriage. A sub-category that refers to marital unions in which both spouses remain(ed) affiliated with their original religious congregations (or with the civil register in the case of no religious congregational membership).

Conversionary in-marriage. A sub-category that applies to marital unions in which the non-Jewish spouse converts to Judaism before or after the marriage.

Conversionary out-marriage. A sub-category that refers to marital unions in which the Jewish spouse joins the religious congregation of his/her spouse.

In addition to the on-site material that can be found in the Jewish Community of Helsinki, the primary sources used for this study consist of minutes of board ${ }^{4}$ meetings, their attachments, administrative documents (such as marriage registries, membership registries, conversion certificates etc.), congregational and personal correspondence, and other documents that are deposited in the National Archives of Finland. Simultaneously, as the research material was being collected, I was one of those responsible for organising the on-site archives of the Jewish Community of Helsinki, a process which contributed much to the assessment of the material. ${ }^{5}$ During the

4 The term that is used for this decisionmaking authority in Finnish (ballintoneuvosto) or Swedish (förvaltningsråd) is often translated as 'Supervisory Board' or 'Administrative Board' in discussions of organisational structures. I decided to use the word 'board' when talking about this entity in English, as it does not serve as a 'clergy' in the community.

5 The project group responsible for the organising project includes docent Simo Muir, Dóra Pataricza and Mercédesz Czimbalmos. 
organisation process it became clear that several documents and sources are missing from the records of the congregation. As a result of this, some additions may still be made to the research material if new data is found. ${ }^{6}$ Considering the small size of Finnish Jewry, in order not to violate the personal privacy of the individuals mentioned in the documents studied, I decided not to disclose their names, with the exceptions of the names of the rabbis, and members who are mentioned by their names in publicly available sources.

\section{Historical background and legislative transitions in Finland}

In order to understand the discussions that shaped the administrative and religious policies of the Jewish Community of Helsinki in the period studied, it is important to know the historical background and legal changes that took place in Finland at the time. Before the twentieth century, the Evangelical Lutheran Church played a central role in Finnish society (Reijonen I 980; Kaila I 923). The social changes that were brought upon Europe by the French Revolution and the Enlightenment (Bleich 2015) did not leave Finland unaffected. At the beginning of the twentieth century, Finland went through numerous legislative and societal changes. The Evangelical Lutheran Church gradually began to lose its unquestioned status, and participation in its activities was declining, even though in 1920, 98 per cent of the Finnish population officially belonged to the Church (Kääriäinen et al. 2005: 49-59; Kupari 201 6: 48).

When Finland became independent of the Russian Empire in I9 17, multiple longawaited policy reforms were implemented.

6 Some of the data presented in this study appeared in Czimbalmos (2018).
The most important decision from the perspective of Finnish Jewry was receiving the right to obtain Finnish citizenship. ${ }^{7}$ Another important legal change was putting the Civil Marriage Act (CMA; Finiish Asetus avioliiton solmimisesta siviiliviranomaisen edessä) into effect. ${ }^{8}$ The Civil Marriage Act made it possible for Finnish citizens to marry people of other faiths without their converting to Christianity (Kaila I 923; UVL267/ I 22; Reijonen I980). Having been granted this freedom, the number of intermarriages between Jewish and non-Jewish citizens started rising rapidly, and intermarriages became a prevalent phenomenon of Finnish Jewish life. This development affected the lives of the individuals and families involved, but also influenced congregational policies and practices (Torvinen I989; Muir 2004; Weintraub 20I7), such as the records of children born to non-Jewish mothers, or the religious practices of men married to non-Jewish woman (NA Kii; NA Vih).

Soon after the CMA took effect, the constitutional right to freedom of religion was implemented by the Freedom of Religion Act (FRA) of 1922 (UVL267/I22), which granted the right to practise religion in public and private, and allowed Finnish citizens to refrain from belonging to any religious community altogether. This act also addressed the question of children whose parents belonged to different religious congregations or who were not members of any at all. According to the FRA, a child belonged to the religious community of his/her father, unless the parents signed a written agreement in which

7 The law on this matter came into effect in I918 (Torvinen I989: 100).

8 The Civil Marriage Act was prepared by the Finnish parliament at the end of the nineteenth century and adopted by the Finnish parliament in I 9I I (Pylkkänen 2OI 2: 53 ). 
they decided otherwise. Moreover, according to paragraph 23 of the Act, religious communities were obliged to keep a registry of their members, and of their children, unless the children officially belonged to other religious congregations (UVL267/I22). This caused significant issues in the administration of the Jewish Community of Helsinki at the time. This regulation remained in force until s 969, when the Finnish law of freedom of religion was changed. From r 970, the child was to follow his/her mother's religious affiliation, unless otherwise decided by the parents (LUM767/1969).

Between r9i9 and r970, a civil register of persons who did not belong to any religious community was kept by the Population Register Centre (PRC; Finnish Väestörekisterikeskus). All officiated marriages and events of birth and death had to be reported to the congregational and civil register that the individuals concerned belonged to. To avoid the problems occurring in the double and decentralised system of population registries over the centuries, the Population Register Centre set up a central register of the population, the present Population Information System (Finnish Väestötietojärjestelmä), in I969. In I97 I, a computer-based register was introduced (Population Register Centre).

\section{Discontinuities in religious leadership 1930-70}

The persona and background of a religious leader have a great impact on the everyday life of a congregation. Even though my main aim in this article is not to discuss the educational or religious backgrounds of the various rabbis who have worked in the Jewish Community of Helsinki in detail, I find it necessary to provide some information about the inclinations of at least some of the rabbis who operated in the community, as they contributed to many of the developments of the administrative processes and religious practices. ${ }^{9}$ The Jewish Community of Helsinki is traditionally Orthodox in its roots, and most of its rabbis considered themselves to be of the Orthodox Jewish tradition. ${ }^{10}$ However, according to Yiddishist Simo Muir, the community and its members did not always follow the standards of Orthodox Judaism in their daily lives (Muir 2004: 3). This observation is also supported by discussions that took place during the twentieth century in the congregation. These debates often appeared on the pages of Hakebila - the community journal - and in the board meeting minutes. The history of the Jewish Community of Helsinki is filled with the reconciliation of Finnish and Orthodox Jewish law, and with the search for an appropriate religious leader and denominational direction for the congregation. In I 924, the board of the congregation laid down the requirements for the appropriate rabbi candidate: they wanted him to be an academically proficient Orthodox Jewish rabbi (NA Bmm 22.4.1924). A few years later, in I93 I, following the earlier stated requirements of the board, the Polish Dr Simon Federbusch became the rabbi of the community until I940 (Muir 2004: 34; Muir and Tuori, in the current issue). ${ }^{11}$

9 The list of all the rabbis between I 867 and I 987 can be found in Torvinen (I989: 224) and in Muir and Tuori's article in the current issue.

10 I would like to emphasise that I do not consider Orthodox Judaism as a unified movement.

11 Federbusch represented the Mizrachi, an Orthodox Zionist movement. He was the chairman of the movement in Galicia between 1924 and I930, before his arrival in Helsinki. Mizrachi was founded in Vilnius in I 902 (Muir 2004: 34). 
In certain periods, the Jewish Community of Helsinki seemed to have searched for new directions to follow. In I947, they requested a statement from Rabbi Elieser Berlinger (rabbi of the congregation, I 946-5 I) in order to be able to differentiate between Orthodox and Reform Judaism, and more importantly, to determine exactly what denomination they fall under. Berlinger's take on the question was straightforward: in view of the Orthodox Jewish rabbis who had operated in the community, it stood on an Orthodox foundation, and hence it was Orthodox (NA Kii). Soon after his response, they also received a letter from Rabbi Simon Federbusch, who agreed with Berlinger (NA Kii; NA Bmm I7.I r.r947). In I957, the Hungarian Mika (Miksa) Weiss (Weisz) became the rabbi of the community and stayed in that position until r 96r. Weiss in his own memoir As Long as I Have Strength: The Autobiography of Rabbi Mika Weiss often mentions that he considered himself Conservative, ${ }^{12}$ whereas the Jewish Community of Helsinki was Orthodox (Weisz 1995: 105-26). Despite his own perception of his religious affiliation, the congregation employed him. In later years, when a new rabbi was sought, the documentation of the community proves that the search was extended not only to Orthodox religious leaders, but also to other denominations. During the second half of the rg6os, the

12 Weiss refers to his denominational affiliation as 'Conservative' both in the English and in the Hungarian version of his book - even though the Conservative movement was not present in Hungary at the time. Taking the Hungarian situation into consideration, Weiss most probably referred to the Neolog faction of Hungarian Jewry. The followers of Neolog Judaism sought to introduce moderate synagogue reforms and religious practices as well as more widespread secular education. For further reading, see Komoróczy (201 2: I IO-23). board sent multiple letters to various nonOrthodox entities ${ }^{13}$ in order to find a new rabbi. During these years, the unified patterns and accepted religious concerns became more fragile as they were criticised by the more liberal congregational members (NA Hpl i 968 , I969; Muir and Tuori, in the current issue).

In I97I the board decided to establish a 'synagogue council' (Finnish synagoganeuvosto) in order to handle questions related to services (NA Bmm 22.3.I97I). After the long-lasting, but unsuccessful, search, Mordechai Lanxner, the former cantor and deputy rabbi, became the rabbi of the community (Torvinen I 989: 224; Muir and Tuori in the current issue). In 1974 he was asked to renew and develop some (religious) practices (NA Bmm i r.2.1974). All in all, the period I930-70 was filled with disputes about bureaucratic and legislative-administrative matters, and some traditions were often questioned by the members of the community and its leadership. In the following parts of this study, I focus on some of the unique and challenging issues relating to intermarriages that arose within the congregation in the period studied. ${ }^{14}$

\section{Rising number of intermarriages}

Before the CMA was implemented, the administration of the Jewish Community of Helsinki recorded only endogamous, religious Jewish marriages (NA Syn, Muu). As

13 The correspondence from the period includes letters send to entities such as the European Board of the World Union of Progressive Judaism and the Jewish Reconstructionist Foundation (NA Hpl I 968, I969).

14 As the archival materials of the Jewish Community of Turku concerning the issues studied here are limited, in this article I decided to focus solely on the Jewish Community of Helsinki. 


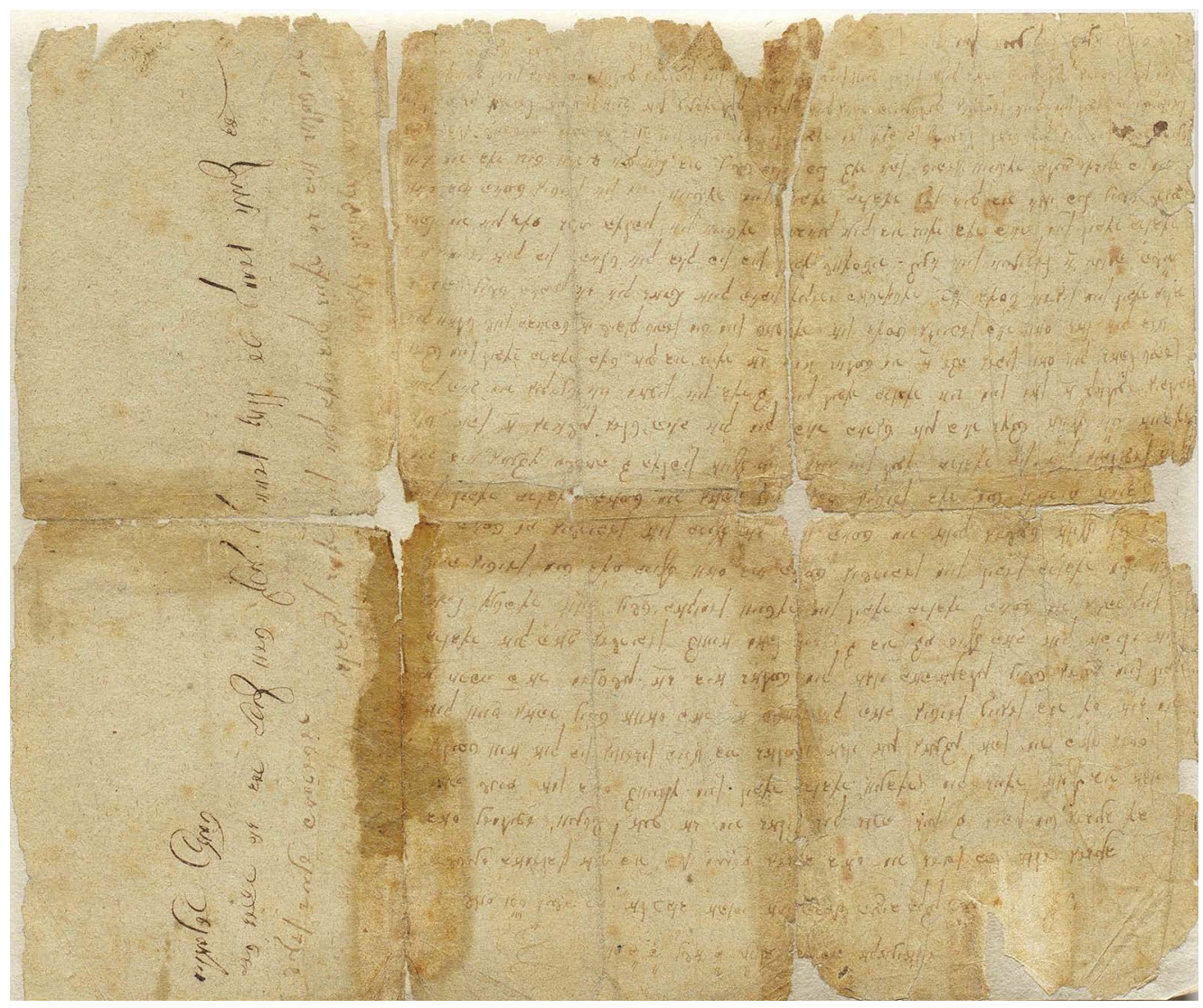

A Yiddish letter concerning matchmaking, 1874. Archives of the Jewish Community of Helsinki, Finnish Jewish Archives, National Archives of Finland.

is shown by Fig. I, the tradition of matchmaking $\left(\right.$ shiddukb) ${ }^{15}$ was also practised in the community (NA Muu).

Shortly after the implementation of the CMA, and later the FRA, marriage patterns in the community started to change. As the following graphs demonstrate, the number of civil marriages in the congregation started to rise rapidly: even many endogamous, Jewish

15 When transliterating Hebrew terminology, in cases of words that I consider embedded in the English language, I decided to use the transliteration that I find the most common (e.g. bar/bat mitzvah). In case of terms I consider rarely used (e.g. shiddukh, taqqanab), the transliteration follows the guidelines of the SBL Handbook of Style. couples chose to officiate their union in the non-religious way. In some instances, the same couple had both a civil and a religious marriage officiated - often one after another. Along with the rising number of endogamous civil marriages, the non-endogamous civil marriages also started appearing in the congregational registries. ${ }^{16}$

16 The graphs presented in this study are primarily based on the entries in the marriage registry book of the Jewish Community of Helsinki ( I 9 I 9-80, NA Vih), as it proved to be the most consistently recorded material available. I also studied the archived population registry notifications of the community (NA Vät, Väi, Väl; JCH Ak r 946-1 980), and Meliza Amity's genealogy site 'Meliza's Genealogy'. The administra- 


\section{Marriages administered in the Jewish community of Helsinki}

(1919-80)

30

25

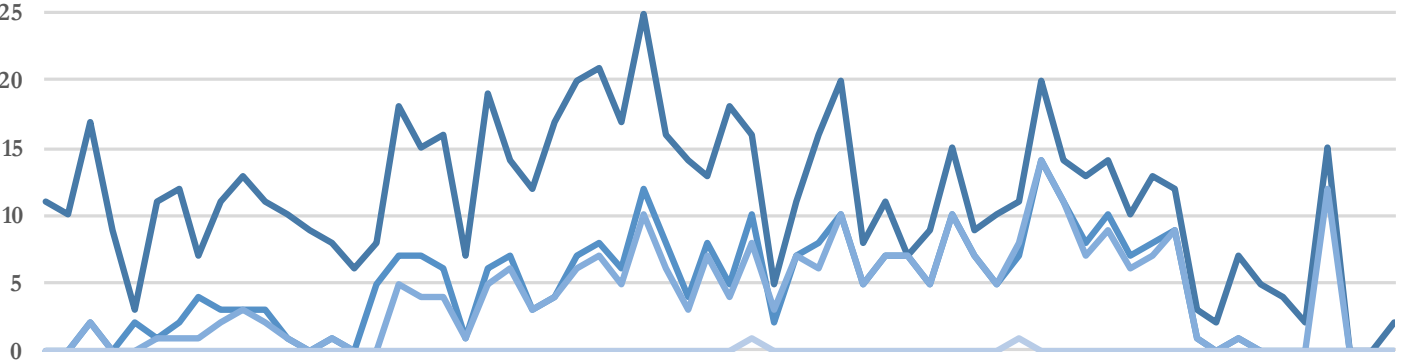

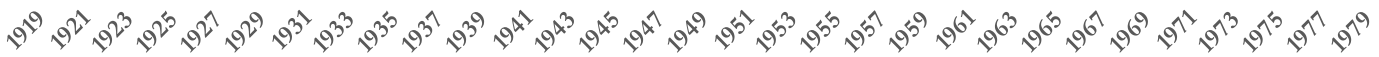

$\longrightarrow$ Marriage Civil marriage Intermarriage $\longrightarrow$ Out-marriage

Graph 1. Marriages administered in the Jewish community of Helsinki (1919-80).

According to the marriage register of the Jewish community of Helsinki ( $\mathrm{JCH} \mathrm{Ak;}$ NA Vih), the first two intermarriages were administered in the community in $\mathrm{I} 92 \mathrm{I}$. Both were mixed marriages, where the nonJewish spouse did not convert to Judaism. As Graph I shows, both the civil marriage rates and the intermarriage rates ${ }^{17}$ started rising in the community significantly from the r930s, and in the r95os for most years

tive documents are often highly inconsistent, so I decided to use them solely as complementary sources (e.g. in cases where necessary information such as community membership of a person, or officiator of a marriage, was missing from the entries). I also sought out official statistics of intermarriage rates within the Jewish Community of Helsinki for the period studied from the Population Register Centre, but I have not received any material so far.

17 As most of the Finnish population belonged to the Evangelical Lutheran Church at the time, it is perhaps not surprising that most of the non-Jewish spouses were from this church (NA Vih; Ak I 946-80). they consisted almost half of all the officiated marriages. I located only two conversionary out-marriages in the register book. ${ }^{18}$ In both cases, the Jewish husband married out of his faith.

In 1956, the Swedish-speaking Finnish journalist Enzio Sevón conducted an interview with two Jewish men in Finland: Isai (Isaij) Davidkin, the chairman of the Jewish Community of Helsinki at the time, and another member of the community, Abraham Schwartzmann talked about the history and present status of their congregation. Schwartzmann expressed his opposition towards mixed marriages but did not seem to refer to the issue as a crucial matter in the community at that time. The fact that the

18 The aim of this study is not to question the halakhic status of the studied individuals. In cases where they did not hold membership of a Jewish community, or when they were members of other religious congregations, I considered them non-Jewish, despite potentially having a halakhic Jewish background. 


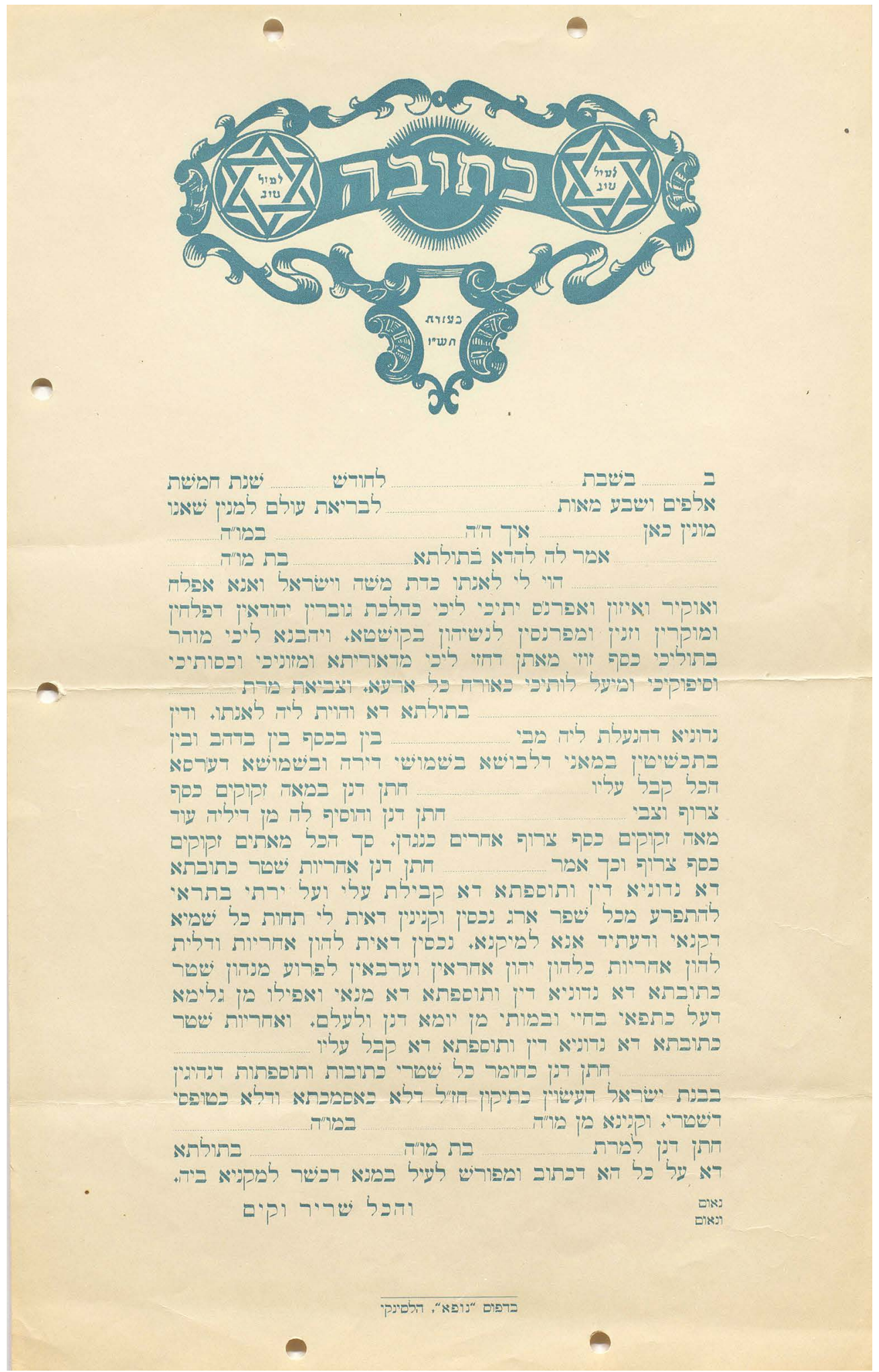

Printed ketubah (prenuptial agreement) used in the Jewish Community of Helsinki, 1946. Archives of the Jewish Community of Helsinki, Finnish Jewish Archives, National Archives of Finland. 


\section{Intermarriages in relation to mixed marriages and conversionary} in-marriages the Jewish Community of Helsinki

$$
\text { (1919-80) }
$$

16

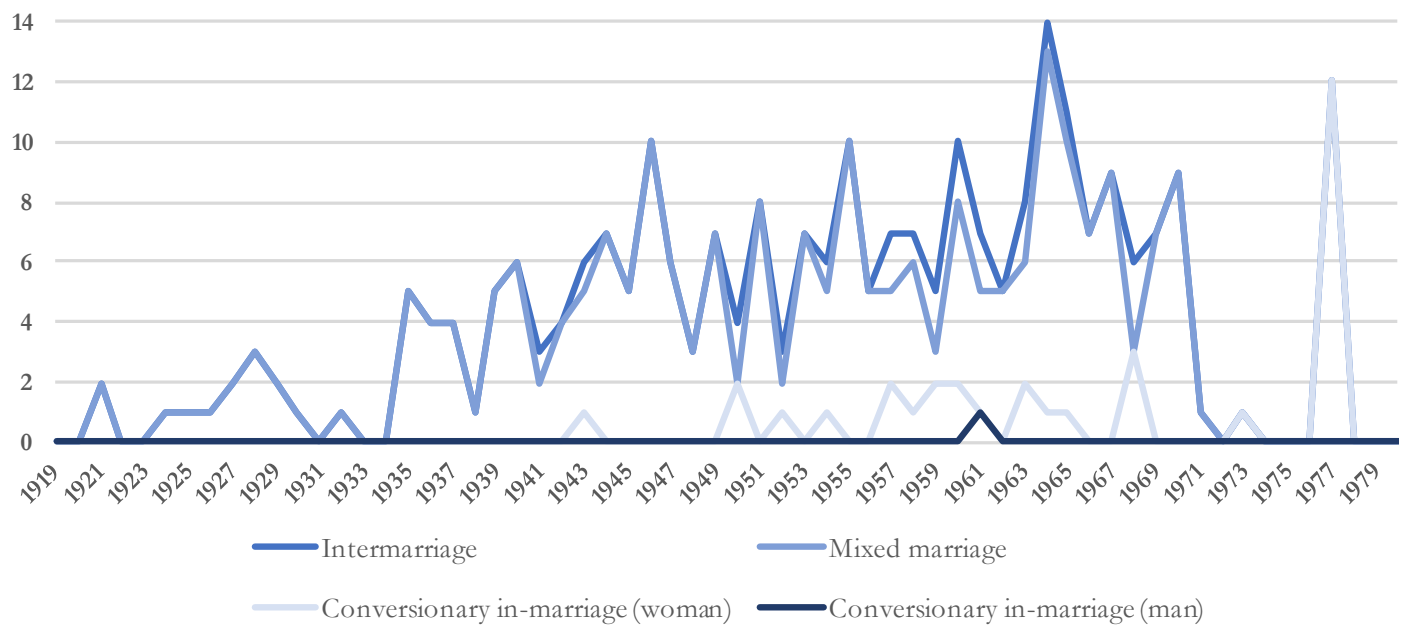

Graph 2. Intermarriages in relation to mixed marriages and conversionary in-marriages the Jewish Community of Helsinki (1919-80).

topic appeared in public discussions suggests the opposite. In addition to the two men, a Jewish woman living in a mixed marriage - who wished to stay anonymous - also answered a few questions from Sevón. She told him about how all her ties to the community and her family were cut when she married a non-Jewish man ('Judarna i Finland I956').

During the r96os, the number of intermarriages kept rising. In a significant portion of these marriages, the spouses kept their respective memberships in their own religious communities (mixed marriage). In thirty-six cases the non-Jewish women converted to Judaism (conversionary in-marriage, woman). In twelve of these cases, the religious marriage took place after an already officiated civil marriage. According to the available sources, there was only one man, who probably converted to Judaism (conversionary in-marriage, man). The vast majority of the members of the congregation who were Jewish by halakhah, the Jewish law, and engaged in intermarriage, were men. ${ }^{19}$ As demonstrated by the two graphs, there was an increase in conversionary in-marriages ${ }^{20}$ in the community in 1977: out of fifteen Jewish religious marriages, twelve were conversionary in-marriages. ${ }^{21}$

I traced one person among the community

19 When referring to these conversions, I refer solely to adult conversions, even if some of the members converted to Judaism as children, as they were children of intermarriages themselves.

20 Given the spatial limitations of this study, I will discuss this matter as well as the matter of adulthood conversions to Judaism in detail in a separate study.

21 I found seven additional conversionary in-marriages in the community's records (JCH Ak I 977). To keep the data presented consistent, I decided not to include them in the graphs. 
members who was the offspring of an intermarriage himself, and was not Jewish by halakhah but was mistakenly registered in the community membership book as a Jew. The leadership of the congregation realised the mistake when the person in question asked for his own son to be registered in the membership book (JCH Bmm 3.Ir.I969). The son's birth certificate is archived in the congregational administration records ( $\mathrm{JCH} \mathrm{Ak}$ r 969). According to the membership book, the son left the community in 1973 ( JCH $\mathrm{HrJFH}$ ). When creating the graphs, I considered him Jewish even though I have not found any documents about his or his son's conversion to Judaism. ${ }^{22}$

\section{First example: community membership of children of non-Jewish mothers}

Mixed marriages are generally viewed negatively by Orthodox Jewish religious leaders, as the children who are born to such unions may follow traditions of other religions. According to traditional definitions and Orthodox Jewish halakhah, Jewishness is inherited on the matrilineal line, but one can also convert to Judaism. ${ }^{23}$ After the implementation of

22 My aim is not to decide on halakhic matters in this article. In order to create interpretable graphs, however, I found it important to mention this detail.

23 According to the most commonly accepted rulings of halakhah, a person who is born Jewish (born from a Jewish mother) is Jewish by halakhah, even if they decide to convert to some other religion. My aim in this article is not to provide detailed arguments about halakhic matters, so I decided to use the most commonly accepted ruling of Jewish law when talking about the issue. Consequently, a person who did not convert to another religion, but is Jewish by halakhah even without being a member of a Jewish community, is Jewish. Despite this, in I 933, the congregation's the CMA, the number of mixed marriages began to rise in the community. Since most of the non-Jewish spouses were women who did not convert to Judaism, most of the children were not Jewish by halakhah. Eventually, the Jewish Community of Helsinki was forced to face the contradiction between Jewish law and Finnish law (FRA), according to which a child was to follow the religion of his/her father - at least until r 969, when the FRA was changed (LUM767/I969). The question of mixed marriages and the children of such marital unions became a permanent issue in the congregation: the correspondence and the minutes of board meetings are filled with discussions about the registration of children of non-Jewish mothers, the potential conversion of these children and requirements concerning their religious upbringing. The board of

board concluded during its meeting that a person who withdraws their membership of the community and registers in the civil register 'withdraws from Judaism' (Swedish utträde ur judendomen) (NA Bmm 25.I 2.1933). This has naturally opened the path to many other problematic processes, for example in the case of burial matters of former members of the congregation. During the same meeting, they decided that withdrawal from congregational membership also results in further sanctions, such as: the person in question loses his place in the synagogue, the circumcision of children of parents who have left the congregation will not be carried out, the marriage ceremony under Jewish law is not given to the person concerned, the person in question is to be excluded from all Jewish associations, and the person who was enrolled in a Jewish parish at the time of birth, but at the time of death belongs to the civil register, should be buried in a territory separate from the Jewish cemetery. A person who wished to rejoin the congregation was first obliged to pay the taxes for the years they had not belonged to the congregation, which amount is determined by the Taxation Board (NA Bmm 2.I.I 934). 
the congregation often consulted the rabbis of neighbouring countries (Denmark and Sweden), but also the chief rabbinate of Israel to seek advice in these matters $(\mathrm{JCH}$ I960-4, I 965-9; NA 1950-4, I 955-9). In I 942, the board of the Jewish Community of Helsinki sent a letter to Rabbi Mordechai Ehrenpreis ${ }^{24}$ and Rabbi Elieser Berlinger, ${ }^{25}$ asking about the enrolment of a child who was born from a non-Jewish mother (NA Bmm I7.6.1942). The board explained the Finnish legal situation, and wrote about the child, who was circumcised but was halakhically non-Jewish. They suggested that a tevilah (full-body immersion in a ritual bath) should take place in the presence of a bet din (a rabbinical court of three), after the child turned three years old. The main concern of the letter was what was to be done if the father of the child did not agree with the tevilab taking place (NA Kii).

A few weeks later, the commissioner of the Mosaic Community of Stockholm (Swedish Mosaiska församlingen i Stockholm), on behalf of Rabbi Ehrenpreis, shared their policies concerning children of mixed marriages: if the couple signed an agreement about the future Jewish upbringing of the children and presented it to the wedding officials, the children of non-endogamous couples were considered members of the Jewish community (NA Kii). A week later, Rabbi Berlinger also responded to the congregation of Helsinki, clarifying that if the mother of the child was not Jewish, the child must convert to Judaism in order to be accepted as a congregation member. If the father explicitly wished the

24 The rabbi of the the Mosaic Community of Stockholm at the time.

25 Elieser Berlinger was the rabbi of the Mosaic Community of Malmö at the time. He worked as a rabbi of the Jewish Community of Helsinki between 1946 and I95 I. child to belong to the Jewish community, he must give a written affirmation of his agreement to the tevilah, so when the suitable time came (age I 3 for a boy, I 2 for a girl) the child was ready for both the conversion procedure and a conjoint bar/bat mitzvah celebration (NA Kii). Interestingly, the child in question was the same person mentioned earlier, who was mistakenly registered in the congregation (NA Bmm 3.Ir.r969). Possibly, the agreement - if it existed - about his conversion was forgotten at the time of his bar/bat mitzvah.

The Finnish legal obligation to register halakhically non-Jewish children in the membership books of the congregation caused further problems in the congregational discussions. One suggestion was to erase the children of non-Jewish mothers from the congregational membership book (NA Bmm I 5.I r.I945). This suggestion was nevertheless disregarded, and during the following meeting, the board agreed that children who had already been entered into the membership book should not be erased, but new children of similar backgrounds should not be entered either. They requested a statement on the matter from Rabbi Berlinger (ibid. r9.1 r.1945). The rabbi was of the firm opinion that halakhically non-Jewish children should not be recorded in the membership books (ibid. 25.2.1946). In view of the problematic situation and growing number of similar incidents, the board boldly decided to submit a request to the Ministry of Education with a proposal for changing the Freedom of Religion Act, so that it would allow a child to follow his/her mother's religious status ( $i b i d$.). Meanwhile, their decision received some criticism because of the way they treated the matter: a group of Jewish academics in Helsinki protested against their procedures (ibid. 28.5.1946). The sources reveal nothing more about this protest. Knowing the circumstances, however, it may 
be assumed that they wanted a more liberal interpretation of the Jewish law, aligned with the Finnish regulations.

In November 1946, a very concrete case relating to the matter of registration arose in the congregation. A community member living in a mixed marriage requested that his halakhically non-Jewish son be entered into the membership book of the congregation. Neither the board nor Rabbi Berlinger agreed to this, even though the secretary of the Ministry of Education concluded in a letter that the community was obliged to accept the child as a member (NA Kii). After the denial of his request, the father and another member of the congregation in a similar situation contacted the Attorney General of Finland (Finnish oikeuskansleri), explaining the situation thoroughly and requesting him to take action in the case. ${ }^{26}$ They considered the registration of their children a solely administrative task officiated by the state and pointed out the often inconsistent record-keeping of the congregation (NA Kii; Czimbalmos 201 8: I68).

The Attorney General requested the Jewish Community of Helsinki to provide an explanation to the magistrate of Helsinki about the case. The board was concerned that if halakhically non-Jewish children were registered in the membership book they would inevitably be considered Jewish. Taking the advice of Rabbi Berlinger into consideration, they described the regulation of matrilineal descent by Jewish law, and shared their opinion, according to which interfering with Jewish law would be a violation of the Freedom of Religion Act (NA

26 Their request was based on paragraph 23 of the Freedom of Religion Act, I922, which states that every religious community is obliged to keep a list of community members and their children.
Bmm I 4.4.1947, 21.4.1947; NA Kii). ${ }^{27}$ They also clarified the case of the mistakenly registered child: during the time of the registration, the congregation was lacking a permanent rabbi, who could have monitored administrative matters (NA Kii; Czimbamos 2018: I67-8). As a further development of the case, the grandfather of one of the children in question - who was a Master of Law with court training (Finnish varatuomari) himself - sent a letter to the congregation in which he briefly summarised the situation. He stated that Rabbi Berlinger's advice ${ }^{28}$ put the board of the congregation in an unpleasant situation. The grandfather considered that the task of the board was to ensure that the rabbi complied with the laws of the country and respected the obligations which the congregation - an organisation recognised under Finnish law - had undertaken (NA Bmm I.IO.I 947).

By the r95os, the number of intermarriages - and most importantly, the number of mixed marriages - became high enough for the board to address the registration issue again. They requested Rabbi Berlinger to lay out the principles of conversion to Judaism (NA Bmm 20.4.I950). Almost a year later, they sought advice from the Mosaic confederation in Copenhagen (Swedish Mosaisk troessamfund i Köpenham ${ }^{29}$ about the registration of children born to non-Jewish mothers (ibid. 20.2.195I). The board took the answer they received into consideration, and decided to record children in the

27 Naturally, if the child had converted to Judaism, they would have earned the right to become a member.

28 The rabbi believed the authorities are 'not competent to settle such disputed matters' (NA Bmm I. Io.I 947).

29 I decided to include the name of the congregation of Copenhagen in Swedish (instead of Danish), as it appears in the board's meeting minutes in Swedish. 
membership book who were, nevertheless, not considered Jewish (ibid. I 5.4.I95 I). In the following years, several entries were made in the book that indicated the religious status of the children as 'non-Jewish' (Swedish icke judelicke judinna) (JCH HrJFH). In most of these instances, the board decided on the matters individually (NA Bmm I2.ro.r953, 2.II.I953). 30 In the case of male children, the brit milab (circumcision) was considered as a necessary 'preparation' for a future conversion to Judaism (ibid. I 5.3.I954). Rabbi Kurt Wilhelm of Stockholm also advised the Jewish Community of Helsinki to comply with Finnish law. He was of the opinion that it is impossible to impose the balakhah on every member of a congregation. He emphasised the responsibility of the congregations: under these circumstances they were obliged to be tolerant, as they could not afford to lose a single Jew (NA Kii).

A few weeks after receiving Wilhelm's letter, the board concluded that children of non-Jewish mothers were considered nonJewish until their conversion took place - at age I 3 for boys, I 2 for girls, as mentioned earlier. In such instances, the parents were requested to give their written consent to give the children a Jewish upbringing, and to proceed with the brit milah of male children, and with the immersion of children of both sexes in the ritual bath (NA Bmm 3.5.1954). ${ }^{31}$ Later the same year, the chairman of the board asked other Jewish authorities - not specified in the minutes - about whether this board decision was correct (from a halakhical point of view) and appeared to have received

30 Some entries cannot be traced back to any meeting minutes.

31 Children of mixed marriages but with Jewish mothers were to be recorded in the membership books - as the children were also Jewish by halakhah. an affirmative answer - the board's view proved to be correct in all respects (ibid. 2.9.1954).

The practice of converting children just before their coming of age ceremonies (bar/bat mitzvah) proved to be the most widely used practice in the congregation. There are a few examples of these early-childhood conversions: in certain cases, Rabbi Elieser Berlinger did agree to the tevilah of children between the ages of 4 and 7 , after which 'the children were considered to be definitively Jewish' (NA Kii; NA Hpl r 967; Czimbalmos 2018). In some instances, the situation appeared to be even more complicated. In one case, a question arose concerning a ro-year-old boy, who had formerly been recorded in one of the Lutheran congregations of Helsinki. The minutes do not provide a clear description of the situation, but the fact that the child was formerly baptised made the board reluctant to enter him into the membership registers. Eventually, to comply with the law, the registration of the child, and other children as well, was conducted (NA Bmm I2.Io.1953, 2.II.I953, I9.I2.I955).

The modification of the FRA modified in I969 (LUM767/. 969) resolved some issues of registration. The number of intermarriages, however, did not cease to rise.

In I970, the congregation issued its own statistics about its membership: on I July I 970, 3 I per cent of the members (I 50 households) were engaged in endogamous marriages and 23 per cent of them (I 4 households) were living in mixed marriages (NA Hpl I970). ${ }^{32}$ In I97 I, a separate list was published concerning children of non-Jewish mothers, born between 1946 and r970. The list included 9I children of 53 families concerned (NA Kii).

32 Nineteen per cent of the members were single, I9 per cent were widows/widowers, and 9 per cent divorced. 
In 1972 , the board agreed to require the parents in mixed marriages 33 to affirm the Jewish upbringing of their children in writing (NA Bmm 29.8.1972) and discussed the possibility of conversions of the members who were already registered in the membership book of the community but had not yet converted to Judaism (ibid. 3.4.1973). In I 973, they issued a statement that defined the congregational protocol for accepting children of non-Jewish mothers into the community, in which they established the same requirements as in 1954 (ibid. 3.5.1954; NA Kii; Czimbalmos 2018: I69). ${ }^{34} \mathrm{Up}$ until very recently, the Jewish Community of Helsinki operated with the same system: children who had at least one Jewish parent could be conditionally accepted into the community. Halakhically Jewish children could be accepted into the community at any time - however, in the case of male children, circumcision was always obligatory. ${ }^{35}$ If the only Jewish parent was the father, the parents had to agree to the Jewish upbringing and to the later conversion of the child. The conversion was to take place right before the children's coming of age ceremonies ( 2 for girls, 13 for boys). At the I 3 March 2018 meeting of the congregation's board, the leadership decided ${ }^{36}$ upon accept-

33 The minutes do not specifically talk about children of non-Jewish mothers, but they most probably referred to the halakhically non-Jewish children in these cases.

34 In addition to the regulation about children of mixed marriages with non-Jewish mothers, it states that non-Jewish mothers were not obliged to convert to Judaism; a child whose mother was Jewish was entitled to become a member of the community at any time. Adults who decided to convert to Judaism were registered as members of the congregation after their conversion took place.

35 Unless the child's medical condition did not make it possible.

36 This decision was preceded by a long-last- ing halakhically Jewish male children into the community whether they are circumcised or not (Hakebila I/201 8: 58).

\section{Second example: the missing taqqanah}

The arguably most complex matter in the community's history in terms of its religious practices concerns a contested and at times also criticised tradition: not granting the aliyab to the Torah to community members (men) living in mixed marriages. This community tradition dates back to the period when Dr Simon Federbusch was the rabbi of the congregation ( $193 \mathrm{I}-4 \mathrm{O})$. He is said to have confined the rights of men married to non-Jews in a taqqanab - a rabbinical regulation or statute (Muir 2004: 5).

As Graph I shows, the first "wave of civil marriages and intermarriages' appeared in the congregation during his religious leadership. According to an interview with one of the former board members, Josef Lefko who knew Rabbi Federbusch in person - the rabbi often talked about the constantly rising number of mixed marriages as a regrettable fact. ${ }^{37}$ Other sources seem to support this statement as well (Hakebila 2/I 999: 30; NA Bmm i 8.I I.I937). As Lefko said, the rabbi 'cursed the community' in a taqqanah and forbade its members who were married to

ing debate and multiple discussions about the matter in the community: in many instances, the non-Jewish father in mixed marriages opposed the idea of circumcision. Often, however, the opposition reflected perceptions of secular Finnish society at large, allowing for the child himself to choose when he reached the appropriate age.

37 It is logical to assume that Federbusch meant marriages in which both spouses kept their 'original religious identities'; hence, I decided to translate the Finnish word seka-avioliitto from the source as 'mixed marriage'. 
non-Jews to perform aliyah to the Torah (Hakehila 2/I999: 30; Muir 2004: 5) or to participate in bar/bat mitzvah ceremonies (Hakebila 2/r999: 30). Federbusch himself claimed that the taqqanah could only be abolished by him or by a religious authority. Interestingly, neither the correspondence nor the minutes of the board meetings of that period include information about such a regulation (NA Kirj. I930-9; NA Bmm I930-4, I935-9). Josef Lefko himself was of the opinion that it may only have been a temporary ban. Federbusch left Finland during the war, but his taqqanab remained in force and the practice connected to it continued, and was only abolished decades later (Hakehila 2/r 999: 30-I). In the mid-r950s, discussions about this 'curse' re-appeared possibly because of the constantly increasing numbers of men affected. The chairman of the board raised the question of whether there was a halakhic restriction concerning Torah reading aimed at men in mixed marriages at all. ${ }^{38}$

A decision was made to consult Rabbi Abraham Jacobson ${ }^{39}$ in Stockholm on the matter (NA Bmm I 6.8.1954). In a letter sent to him the following day, the board requested his response concerning the question of Torah reading and also concerning acceptance of children of non-Jewish mothers into the congregation before a certain age. The next record in the minutes about this matter concerns the decision to contact Rabbi Isaac Herzog, the Askhenazi chief rabbi of Israel, on the question (ibid. 4.IO.I954). The chairman of the board expressed his willingness to

38 One potential halakbic explanation of the matter can be found in Cohen (I 988: 79-84).

39 Jacobson's response is not available in the congregational archives; it may not exist at all or it may not have been archived. visit the relevant authorities in Israel to discuss the issue with them (ibid. 25.10.1954). Months later, the response from Rabbi Herzog came: he did not want to interfere with the accepted practice of the congregation (ibid. 31.5.1955).

The board returned to the issue in the autumn of 1956 . The chairman doubted that the rabbinical edict of Federbusch would have any effect on the number of mixed marriages, and the majority of the board members were in favour of abolishing the taqqanah. Yet they considered the issue out of their power, and did not abolish it after all. The chairman, showing his solidarity with the community members in mixed marriages, decided to refuse doing aliyab himself, until the taqqanah was invalidated. He was, however, of the opinion that 'the members who live in mixed marriages are as good Jews as he is' (NA Bmm 26.I I.r 956).

In 1957, when Rabbi Dr Mika Weiss was interested in taking up the position as rabbi of the congregation, he also consulted the taqqanab and the custom connected with it. After the conversation with Weiss, the chairman of the board rescinded his earlier decision, and agreed to do aliya when asked after all, to avoid being disrespectful towards the Torah. He also emphasised that the board would keep working on providing the right to aliyab for all men in the community (NA Bmm 3.6.1957). Coming from Hungary, Rabbi Weiss most probably had not faced a similar situation in any of the Jewish communities that he had been involved in. He did not want to abolish the taqqanab alone, so he contacted the Nordic Rabbinical Council. Dr Marcus Melchior, the rabbi of Copenhagen, informed the congregation of the possibilities of suspending the ban (ibid. Io.8.1958), to which he saw no obstacles (NA Hpl I 968). Despite all the efforts and correspondence, not allowing the aliyah of members in mixed 
marriages remained in practice until more than a decade later, as the board wanted to clarify the issue one more time (NA Bmm 23.I2.I968).

On 12 December I968, the congregation sent a letter to the embassy of Israel in Helsinki, asking them to forward a cable to the chief rabbinate of Israel. They requested an urgent appointment with the chief rabbi of Israel 'to discuss religious problems of a serious nature actualised by mixed marriages jeopardising the unity' of the congregation (NA Hpl i 968). Less than two weeks later (24.I 2.I 968) another letter was sent to Rabbi Simon Federbusch. Not having found the taqqanah amongst other official documents of the community, they asked their former rabbi to give them the details about it and asked him to send a copy if possible (NA Hpl I 968). During the spring of 1969 , another letter was sent to Israel, this time to the Sephardi chief rabbi, Ovadia Yosef, about the same issue. In his response, the chief rabbi concluded that the members can be called to do aliyah as they are still Jewish - even if they 'sinned greatly' by marrying a non-Jew. Answering the other question that was addressed to him in the same letter, he wrote that the children of these members can also be called to the Torah, given that they had converted to Judaism (NA Hpl I 969). According to the available sources, Rabbi Federbusch himself never replied to the letter sent to him. In fact, as an obituary in The New York Times of 22 August 1969 proves, he passed away on 2 I August I969, at the age of 77 (NA Hpl I 969). The community decided to open up to possibility of aliyah to all adult male members in the I 970s (Hakebila 2/r 999: 30).

\section{Conclusions}

The aim of this article has been to contribute to international research by deepening the understanding of the unique Jewish
Community of Helsinki by examining a set of archival documents that include valuable information about the policies and traditions of the congregation during the period I93070 , a time when the legal and societal changes that Finnish society had recently been undergoing made an impact on the community.

The special legal and societal circumstances and the minority status of Jews in Finnish society led to a significant increase in intermarriages in the Jewish Community of Helsinki. Indeed, they became a distinctive characteristic of the traditionally Orthodox Finnish Jewry. This increase and the lack of continuous guidance from a permanent rabbi meant that the leadership of the congregation often faced situations where they needed to create and maintain a balance between Orthodox Jewish traditions and secular Finnish society and its legal requirements. As the theoretical framework of this study has suggested, interreligious marriages brought about changes in the religious practices and administrative system of the Jewish Community of Helsinki. The decision-making processes of the congregation were challenged and affected significantly, and the discrepancies between the doctrinal organisation and the vernacular adaption of the regulations increased in the congregation. As a result, the congregation did not modify its doctrines or treat the halakbah flexibly, but rather attempted to resolve the problems through the guidance they acquired from external Jewish authorities. Amongst the issues that arose in the period under study as a result of rising numbers of mixed marriages, I have investigated two specific issues in this study.

The first relates to the registration of children of mixed marriages in the community. The Freedom of Religion Act of 1922 addressed the congregational adherence of children of mixed-religion parents. According to the law up to I 969 , the child was to follow the 
father's religion. From I 970 onwards, a child was to follow the mother's religion. As the Orthodox Jewish halakbah followed by the community traced Jewishness on the matrilineal line, the registration of children from non-Jewish mothers in the congregational membership book was problematic from the religious point of view, but obligatory from the Finnish legal point of view. The clarification of this question included consultations with secular and religious authorities, lengthy internal discussions and correspondence with the persons involved. Nevertheless, the community only resolved the issue entirely when the Freedom of Religion Act was changed in I969.

The other issue that emerged from the increased number of mixed marriages and lack of permanent rabbinical guidance was related to the taqqanah created by Rabbi Dr Simon Federbusch during the I930s. This matter took around forty years for the community to resolve. The rabbinical statute confined the rights of men who were engaged in mixed marriages, and restricted them from getting an aliyah to the Torah. As with the registration of children of non-Jewish mothers, the taqqanab was only invalidated after various lengthy internal discussions of the board and external correspondence with various rabbinical authorities.

These two matters are only fragments of the discussions that arose in the Jewish Community of Helsinki as a result of intermarriages. Nevertheless, they demonstrate the most common concerns that emerge from discussions about the topic of exogamous Jewish relationships both among scholars of the field and in religious communities. Finnish society is undergoing rapid secularisation. Its norms and trends are changing constantly. These changes naturally reflect on the local religious communities as well. There are various contradictory traditions practised in the Jewish Community of Helsinki to this day, some of them rooted in the phenomenon of exceptionally high rates of intermarriages. In order to understand the community and its practices better, further research on these marital relations and their effects is necessary.

\section{Mercédesz Czimbalmos} is a doctoral student in comparative religion at Åbo Akademi University. Her background is in Jewish studies, comparative religion, cultural studies and Japanese studies. Her research interests include contemporary Judaism, and intercultural

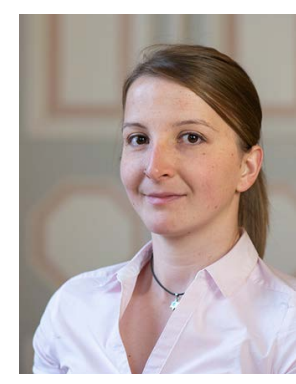
and interreligious encounters. Currently, she is working on her doctoral dissertation, studying intermarriages in Finnish Jewish communities. Her main focus is on discourses around intermarriage and conversion within Finnish Jewry.

\section{Bibliography}

\section{Archival sources}

National Archives of Finland (NA) Finnish Jewish Archives, Archives of the Jewish Community of Helsinki

Bmm. Board minutes I919-29, box 39: 22.4.1 924 ; $1930-4$, box 40 : 5.I2.1933, 2.I.1934; 1935-9, box 4I: I8.II.1937, I940-9, box 42: I 7.6.I942, I 5.I I.I945, I9.II.I945, 25.2.1946, 28.5.1946, I I.II.I 946, I.IO.I947, I 7.I I.I 947, I 4.I.I 948; I 950-4, box 43: 20.4.1 950, 20.2.195 I, I 5.4.1 95 I, I 2.10.1953, 2.II.1953, I 5.3.1954, 3.5.1 954 , I6.8.1954, 2.9.1954, 4.IO.I 954 , 25.10.1954; I $955-59$, box 44: 3I.5.I955, I9.I 2.1955, 26.II.1956, 3.6.1 957, 10.8.1 $95^{8}$; 1968-77: box 45: 23.I2.I968, 22.3.197 I, 29.8.1972, 3.4. I 973 , I I.2.1 974

Hpl. Appendices to the board minutes 1967, I968, r 969, r970

Kii. Controversy concerning registering children born to non-Jewish mothers, I $946-73$, box I63 
Kirj. Correspondence I930-I, box 7I; 1 $932-3$, box 72; 1933-4, box 73; I $934-5$, box 74; I $936-7$, box 75; I $938-9$, box 75

Muu. Other records, box 432

Syn. List of births and marriages I 903-I 9 , box 7

Väi. Notifications give to the Population Register Center before 197 I, A-M, box I4; N-Z, box 15

Väl. Population census records, A-K, box I 6

Vät. Information given to the Population Register Center (1 869-73), box I 3

Vih. List of marriages, I 9 19-80, box 9 Jewish Community of Helsinki (JCH)

Ak. Asiakirjat I 946-80: I969, I977

$\mathrm{Bmm}$. Board minutes i 960-4. Protokoll I 960-4; 1965-9. Protokoll I965-9: 3.I I.1969

Hakebila 2/I 999, I/201 8

$\mathrm{HrJFH}$. Hufvud-Register öfver medlemmar Judiska Församlingen i Helsingfors, I 9 19-

\section{Other sources}

Ammerman, T. Nancy, I 998. 'Culture and identity in the congregation', Studying Congregations: A New Handbook, ed. Nancy T. Ammerman, Jackson W. Caroll, Carl S. Dudley and William McKinney (Nashville, Abingdon Press), pp. 78-I05

Berman, C. Lila, 2o ro. 'Blame, boundaries, birthrights in Jewish intermarriage in midcentury America', Boundaries of Jewish Identity, ed. Susan A. Glenn and Naomi B. Sokoloff (University of Washington Press), pp. 9-1o9

Bleich, Judith, 20 I 5. Intermarriage in the early modern period', Conversion, Intermarriage and Jewish Identity, ed. Robert S. Hirt, Adam Mintz and Marc D. Stern (New York, Ktav) pp. 3-47

Buckser, Andrew, 2003. After the Rescue: Jewish Identity and Community in Contemporary Denmark (New York, Palgrave Macmillan)

CMA, r9 I7. 'Asetus avioliiton solmimisesta siviiliviranomaisen edessä', Suomen Suurirubtinaanmaan asetuskokoelma, no. IOI, I9I7

Cohen, J. Simcha, 1998. Intermarriage and Conversion: A Halakbic Solution (Hoboken NJ, Ktav)

Czimbalmos, Mercédesz, 201 8. 'From Yidishe khasene to civil marriage', Jewish Studies in the
Nordic Countries Today, ed. Ruth Illman and Björn Dahla, Scripta Instituti Donneriani Aboensis, 28 (Turku/Åbo, Donner Institute), pp. I59-74, doi: <https://doi.org/Io.30674/ scripta.7007I >

DellaPergola, Sergio, 2003. 'Jewish out-marriage: a global perspective', International Roundtable on Intermarriage, Brandeis University, I 8.I2.2003, <http://research.policyarchive. org/I I 565.pdf> (accessed I.8.2017)

Dencik, Lars, 2003. “Jewishness” in postmodernity: the case of Sweden', New Jewish Identities: Contemporary Europe and Beyond, ed. Zvi Gitelman, Barry Kosmin and András Kovács (Budapest, Central European University Press) pp. 75-105

Fishman, B. Sylvia, 2015. 'Diagnosing challenges to contemporary Modern Orthodox families', Conversion, Intermarriage and Jewish Identity, ed. Robert S. Hirt, Adam Mintz and Marc D. Stern (New York, Ktav) pp. 47-65

Fishman, B. Sylvia, and Steven M. Cohen, 2017. Family, Engagement and Jewish Continuity Among American Jews (Jerusalem, The Jewish People Policy Institute), $<$ http://jppi.org.il/new/en/article/ english-raising-jewish-children-researchand-indications-for-intervention/englishfamily-engagement-and-jewish-continuityamong-american-jews/\#.XBACk2gzY 2 w > (accessed 8.12.2018)

Graham, David, 2004. European Jewish Identity at the Dawn of the 21st Century: A Working Paper, JPR Report, <http://archive.jpr.org.uk/ download? id $=\mathrm{I} 477>($ accessed 23.9.201 8$)$ 2016. Jews in Couples: Marriage, Intermarriage, Cohabitation and Divorce in Britain (London, Institute for Jewish Policy Research), <http://archive.jpr.org.uk/ download?id=2792> (accessed 7.12.2018)

Hirt, S. Robert, Adam Mintz, and Marc D. Stern (eds), 2015. Conversion, Intermarriage and Jewish Identity (New York, Ktav)

Honkasalo, Marja-Liisa, 20 I 5. 'If the Mother of God does not listen: women's contested agency and the lived meaning of the Orthodox religion in North Karelia, Journal of American Folklore, I 28(507), pp. 65-92

Huotari, Voitto, 1975. Ortodoksin ja luterilaisen avioliitto (Helsinki, Suomalainen teologinen kirjallisuusseura)

'Judarna i Finland 1956'. Svenska YLE, 24.I.20 I I, <https://svenska.yle.fi/artikel/20I I/or/27/ judarna-i-finland $>$ (accessed 2.10.2019) 
Kääriäinen, Kimmo, Kati Niemelä, and Kimmo Ketola, 2005. Religion in Finland: Decline, Change and Transformation of Finnish Religiosity (Tampere, Church Research Institute)

Kaila, Erkki, I923. Uskonnonvapauslaki ynnä siihen liittyvät lait ja asetukset (Helsinki, Otava)

Komoróczy, Géza, 20 I 2. A zsidók története Magyarországon, II (Pozsony, Kalligram)

Kupari, Helena, 20 I 6. Lifelong Religion as Habitus: Religious Practice among Displaced Karelian Orthodox Women in Finland (Leiden and Boston, Brill)

$\mathrm{LUM}_{767 / 1969 .}$ Laki uskonnonvapauslain muuttamisesta, 767/r 969, <https://www. finlex.fi/fi/laki/alkup/ı969/ı $9690767>$ (accessed 2.10.2019)

Meliza's Genealogy. Meliza Amity's genealogical website, <www.amitys.com> (accessed $3 \cdot 4.2019)$

Muir, Simo, 2004. Yiddish in Helsinki: Study of a Colonial Dialect, Studia Orientalia (Helsinki, Finnish Oriental Society)

PRC. Väestörekisterikeskus, Population Register Center's website, <http://vrk.fi/historia> (accessed 2.10.2019)

Pylkkänen, Anu, 20 I 2. Vaibtoehto avioliitolle. Seksuaalisuudesta ybteistalouden sä̈ntelyyn (Tampere, Vastapaino)

Reijonen, Mikko, I980. Uskonnonvapauden toteuttaminen Suomessa vuosina 1917-1922 (Helsinki, Suomen Kirkkohistoriallinen Seura)

Sarna, D. Jonathan, 201 5. 'American Orthodox responses to intermarriage', Conversion, Intermarriage and Jewish Identity, ed. Robert S. Hirt, Adam Mintz and Marc D. Stern (New York, Ktav) pp. 409-27

Sasson, Theodore, Leonard Saxe, Fern Chertok, Michelle Chain, Shahar Hecht, and Graham Wright, 201 5. Millennial Children of Intermarriage: Touchpoints and Trajectories of Jewish Engagement (Waltham MA, Brandeis University), <https://www. brandeis.edu/cmjs/pdfs/intermarriage/ MillennialChildrenIntermarriager.pdf> (accessed 2.10.2019)

Tank-Storper, Sébastien, 20r 3. 'Trouble dans la judéité: mariages mixtes, conversions et frontières de l'identité juive', Ethnologie française, 43, p. 59I-9, doi: <https://doi. org/Io.39 I 7 /ethn. I 34.059 I >

Tobin, A. Gary, and Katherine G. Simon, 1 999. Rabbis Talk about Intermarriage (San Francisco, JCR)
Torvinen, Taimi, I 989. Kadimah. Suomen juutalaisten historia (Helsinki, Otava)

UVL267/I 22. Uskonnonvapauslaki, $267 /$ I $922,<$ http://www.finlex.fi/fi/laki/ alkup/r 922/1 9220267> (accessed 3.4.2017)

UVL $2003 / 453$, Uskonnonvapauslaki, 6.6.2003/453 267/1922, <https://www.finlex. fi/fi/laki/ajantasa/2003/20030453?search\% ${ }_{5} \mathrm{~B}$ type $\%{ }_{5} \mathrm{D}=$ pika\&search $\%{ }_{5} \mathrm{~B}$ pika\% ${ }_{5} \mathrm{D}=$ =uskonn onvapauslaki> (accessed 5.I I.20I7)

Vuola, Elina, 2or 8. 'Jewish Women in Finland', Embodied Religion website, <http://blogs. helsinki.fi/embodied-religion/vuola-jewish/> (accessed 2.10.2019)

Weintraub, Daniel, 20 I7. 'Juutalaiset ja juutalaisuus Suomessa', Monien uskontojen ja katsomusten Suomi, ed. Ruth Illman, Kimmo Ketola and Jussi Sohlberg (Tampere, Kirkontutkimuskeskus), pp. i 16-26

Weisz, Miksa, I995. Amíg erömból telik... (Debrecen, Hungary) 